\title{
CROSSING THE SEA EN ROUTE TO AFRICA: \\ AUTUMN MIGRATION OF SOME Accipitriformes OVER TWO CENTRAL MEDITERRANEAN ISLANDS
}

\author{
Nicolantonio Agostini, Guido Premuda, Ugo Mellone, Michele Panuccio, \\ Daniela Logozzo, Enrico Bassi and Leonardo Cocchi
}

\begin{abstract}
Agostini N., Premuda G., Mellone U., Panuccio M., Logozzo D., Bassi E.,Cocchi L. 2004. Crossing the sea en route to Africa: autumn migration of some Accipitriformes over two Central Mediterranean islands. Ring 26, 2: 71-78.

Observations were made on the autumn migration of Accipitriformes over the islands of Marettimo and Pantelleria, located between western Sicily and Tunisia (Central Mediterranean). A total of 7451 raptors was counted between 24 August and 12 September 2003, mostly adult Honey Buzzards Pernis apivorus - 4045, and Black Kites Milvus migrans - 2489. Mixed-age flocks were regularly reported for the Black Kite (1956 adults and 533 juveniles estimated) confirming information transmission concerning orientation behaviour in this species. Although in the Honey Buzzard juveniles tend to migrate later than adults, crossing the Mediterranean on a broad front mostly after mid-September, we observed some mixed-age flocks, estimating the passage of 3830 adults and 215 juveniles. In particular, over Pantelleria we recorded in seven cases juveniles in flocks of adults heading towards WNW, presumably learning (similarly to juvenile Black Kites) the shortest route over water to reach Africa from this site. A total of 72 Egyptian Vultures Neophron percnopterus - 62 adults, 6 juveniles and 4 sub-adults - was counted over Marettimo confirming that their greatest concentration during autumn migration through Italy occurs at this island. In this species, all juveniles were seen migrating in flocks of adults. Finally, the passage of hundreds of Marsh Harriers Circus aeruginosus was reported, mostly over Pantelleria. Among adult harriers, it was possible to estimate the passage of birds belonging to different sex classes; unlike in the previous studies made in central, southern continental Italy and Malta during autumn migration, adult females outnumbered adult males (372 vs 298 individuals). Finally, considering the huge number of Accipitriformes observed, Pantelleria, so as Marettimo, should be enclosed among Important Bird Areas for the autumn migration of raptors in the Mediterranean basin.
\end{abstract}

Dr. N. Agostini (corresponding author), Via Carlo Alberto 4, 89046 Marina di Gioiosa Jonica (RC), Italy, E-mail: nicolantonioa@tiscalinet.it; G. Premuda, Via G. Pierluigi Da Palestrina 20, 40141 Bologna, Italy; U. Mellone, Via Umberto I 28, 73100 Lecce, Italy; M. Panuccio, Via Mario Fioretti 18, 00152 Roma, Italy; D. Logozzo, Via Carlo Alberto 4, 89046 Marina di Gioiosa Jonica (RC), Italy; E. Bassi, Via Provinciale 69, 24022 Alzano Lombardo (BG), Italy; L. Cocchi, Via Ruffini 12, 41010 Piumazzo (MO), Italy.

Key words: migration, Accipitriformes, Central Mediterranean 


\section{INTRODUCTION}

Although Accipitriformes generally tend to migrate exploiting thermal currents over land to limit energetic costs, some species with relatively long wings, such as ospreys, harriers and kites, undertake long water crossings using powered flight (Kerlinger 1989). In these cases, raptors often converge over islands used as stopover sites or to exploit soaring flight. During autumn migration, considerable numbers of Accipitriformes cross the Central Mediterranean at its narrowest point, between western Sicily and the Cap Bon Peninsula (Fig. 1). To date, in this area observations were made over the island of Marettimo located about $30 \mathrm{~km}$ off western Sicily and $130 \mathrm{~km}$ NE of the Cap Bon peninsula. There, thousands of raptors are recorded each season, nearly all between the end of August and the first half of September (Agostini et al. 2000; Agostini et al. 2001, 2002; Agostini et al. 2004). However, sporadic observations made over the island of Pantelleria, located about 110 km south of Marettimo (Fig. 1), suggest that the migratory flow of Accipitriformes across this Mediterranean area occurs on a broader front. In particular, at this site, Galea and Massa (1985) recorded a flock comprising 400 Black Kites Milvus migrans on 6 September 1978 while the passage of 230 Honey Buzzards Pernis apivorus was reported on 28 August 2002 (Ruggieri pers. obs.). The aim of this study was to make a survey of the migratory flow at these two islands by contemporaneous observations during the peak period.

\section{STUDY AREA AND METHODS}

Observations, aided with binoculars and telescopes, were made from 24 August to 12 September 2003. Marettimo is a mountainous island $\left(12 \mathrm{~km}^{2}\right)$, about $30 \mathrm{~km}$ off western Sicily and $20 \mathrm{~km}$ west of the islands of Levanzo and Favignana. As mentioned above, this island is located at the narrowest point of the central Mediterranean, about $130 \mathrm{~km}$ NE of the Cap Bon promontory (Tunisia, Fig. 1). Monte Falcone is its highest relief, reaching $686 \mathrm{~m}$. The observation post was located at the altitude of $c a 500 \mathrm{~m}$. At this site no observations were made between 10 and $12 \mathrm{Sep}-$ tember. Pantelleria is a volcanic island $\left(84 \mathrm{~km}^{2}\right)$, about $110 \mathrm{~km} \mathrm{SW}$ of western Sicily and $70 \mathrm{~km}$ ESE of the Cap Bon Peninsula (Fig. 1). The observation post was located at the altitude of $c a 600 \mathrm{~m}$, along the slopes of Montagna Grande, its highest relief $(836 \mathrm{~m})$. To limit eventual pseudoreplication of data, at the island of Marettimo birds seen flying back towards western Sicily were not considered. Moreover, at both sites the count was interrupted when raptors were seen stopping migration; in these cases, for each species the maximum number of birds seen at the same time was reported. Finally, birds roosting at the two sites were counted only when birds were not recorded the following morning. In the case of adult Marsh Harriers Circus aeruginosus it was possible to determine the age and sex of some birds by obser- 


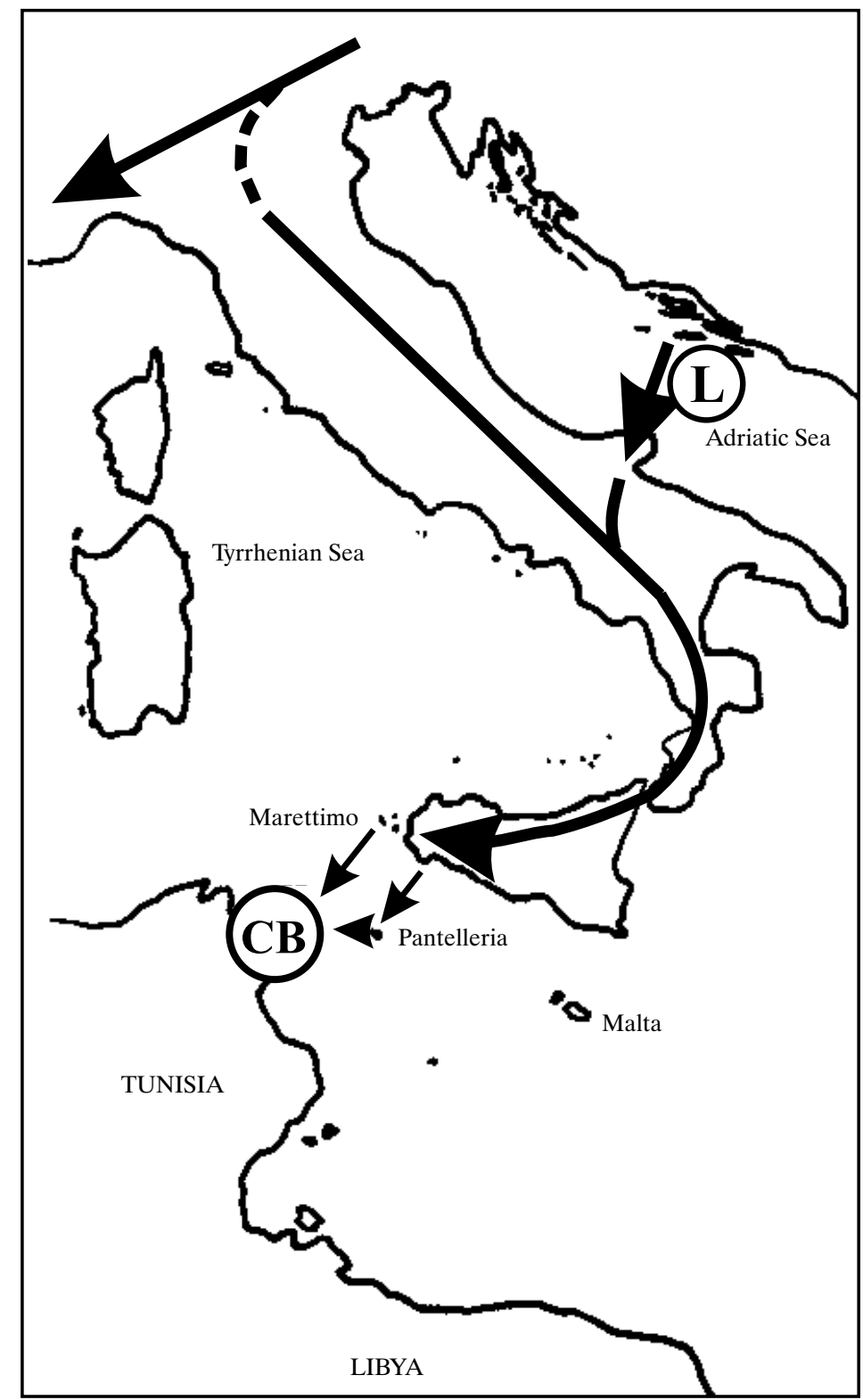

Fig. 1. The study area and approximate routes (arrows) used by adult Honey Buzzards Pernis apivorus during autumn migration through Italy en route to Africa. L - Lastovo, CB - Cap Bon Peninsula.

vation of their plumage (Forsman 1999). The total of adults and juveniles was derived by multiplying their proportions in the sample of identified individuals following the method used in previous studies (Kjellén 1992, Agostini and Logozzo 1997). In order to exclude a bias due to the better identification of adult males, as regards to the Marsh Harrier, the proportion of females and juveniles was estimated divid- 
ing unidentified individuals of the group female/juvenile between the two age groups according to their proportion among the identified birds (Agostini and Logozzo 2000, Agostini et al. 2001, Panuccio et al. 2002, Agostini et al. 2003).

\section{RESULTS AND DISCUSSION}

At the two sites a total of 7451 raptors was counted, out of them 3358 were seen over Marettimo and 4093 over Pantelleria. The proportion of species recorded was different at the two sites: over Marettimo the Black Kite was that mostly observed, conversely the Honey Buzzard over Pantelleria (Table 1). Raptors reached the island of Marettimo from E leaving the site heading SW. Over Pantelleria birds were seen reaching the site from NE. Here, 506 Black Kites and 2631 Honey Buzzards left the island towards WNW, choosing the shortest route to reach Africa from this site (Fig. 1) and showing true navigational abilities as the Cap Bon Peninsula was nearly always out of sight. Altogether 232 Black Kites and 95 Honey Buzzards roosted at Pantelleria and were not seen the following morning. Considering the total numbers of birds seen at the two sites, the daily variation of the migratory flow of both Black Kite and Honey Buzzard showed four pulses of movements (Fig. 2). Among Black Kites the passage of 1956 (78.6\%) adults and 533 (21.4\%) juveniles was estimated. In this species, flocks comprising individuals belonging to the two age classes were regularly reported confirming the transmission of information concerning orientation behaviour between experienced and inexperienced birds (Agostini and Logozzo 1997, Agostini et al. 2000). The proportion of juveniles was lower among Honey Buzzards - 3830 (94.7\%) adults and 215 (5.3\%) juveniles esti-

Table 1

Raptors observed over the islands of Marettimo and Pantelleria between 24 August and 12 September 2003

\begin{tabular}{|l|c|c|c|}
\hline & Marettimo & Pantelleria & Total \\
\hline Pernis apivorus & 1319 & 2726 & 4045 \\
\hline Milvus migrans & 1751 & 738 & 2489 \\
\hline Circus aeruginosus & 196 & 611 & 807 \\
\hline Neophron percnopterus & 72 & 2 & 74 \\
\hline Circus pygargus & 3 & 7 & 10 \\
\hline Pandion haliaetus & 4 & 4 & 8 \\
\hline Buteo buteo* & 4 & 4 & 6 \\
\hline Hieraaetus pennatus & 5 & 1 & 3 \\
\hline Aquila pomarina & 3 & 0 & 1 \\
\hline Buteo rufinus & 1 & 0 & 6 \\
\hline
\end{tabular}

* including 2 indiv. of B. b. vulpinus 


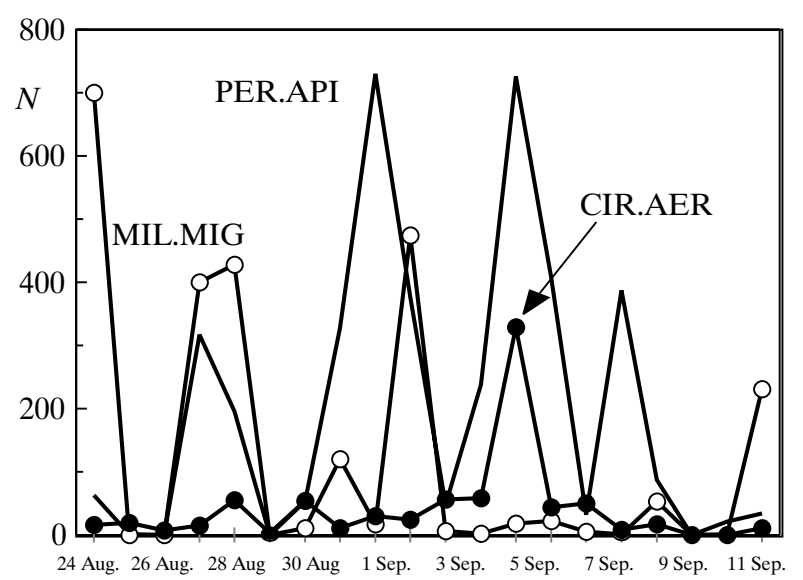

Fig. 2. Daily variations of the migratory flows of Honey Buzzards (PER.API), Black Kites (MIL.MIG) and Marsh Harriers (CIR.AER) through the Channel of Sicily between 24 August and 12 September 2003.

mated. In seven flocks we recorded juvenile Honey Buzzards leaving Pantelleria towards WNW following adult birds. Although in this species juveniles tend to migrate later than adults (Kjellén 1992, Agostini and Logozzo 1995), our results confirm that some young birds migrate in flocks of adults during their first migration possibly learning the shortest route to cross the central Mediterranean (western Sicily-Tunisia; Agostini et al. 1999, Agostini et al. 2000). On the contrary, juveniles migrating later than adults, after the second week of September, cross the central Mediterranean on a broader front undertaking long powered flights over water between the Italian Peninsula and Tunisia (part of them via western Sicily) and southern Sicily and Libya via Malta, apparently moving along axis genetically defined (Agostini and Logozzo 1995, Agostini et al. 1999, Agostini et al. 2002, Agostini et al. 2004). The thousands of Honey Buzzards recorded in this study do not agree with the conclusion that mostly adults belonging to the population breeding in central Italy cross the central Mediterranean during autumn migration (Agostini and Logozzo 1995, 1997). It has been confirmed by recent observations made over the island of Lastovo (Croatia; Fig. 1) where, during sporadic observations carried out between 24 August and 3 September 2001, Schneider-Jacoby (2001) reported the passage of 221 birds en route towards southern Italy. Unfortunately the author did not report data concerning the age of migrants.

Over Pantelleria, it was impossible to detect carefully the route used by Marsh Harriers to reach Africa. Because these birds migrate mostly singly or in small loose flocks (Kerlinger 1989), they soon disappeared from observers' sight apparently towards southwest. Moreover, after the long sea crossing between western Sicily and Pantelleria, individuals often stopped migration going hunting. Finally, at least 120 Marsh Harriers roosted at the site leaving the island undetected in the following early morning. Marsh Harriers regularly undertake long water crossings, both during autumn and spring migration, mostly moving along NE-SW axis and using is- 
lands as stopover sites (Rebassa 1995, Agostini 2001, Agostini et al. 2001, Panuccio et al. 2002, Agostini et al. 2003). At the two sites we estimated the passage of 298 (36.9\%) adult males, $372(46.1 \%)$ adult females and 137 (17.0\%) juveniles, and reported an evident peak on 5 September (Fig. 2). Thus, among adults, females outnumbered males $\left(\chi^{2}=7.95, d f=1, p<0.01\right)$. This result does not agree with data recorded in previous studies made in central, southern continental Italy and over the island of Malta in 1996 and 2002 when adult males outnumbered adult females during the first half of September (Agostini and Logozzo 2000, Agostini et al. 2003). Unlike the Black Kite and Honey Buzzard, the European population of the Marsh Harrier is partially migrant (Cramp and Simmons 1980). In particular, at least among adults, considerable numbers of females winter in central Europe (Chiavetta 1981, Clarke 1995, Agostini and Logozzo 2000). Female harriers, being larger than males, are able to capture larger prey and, probably, tolerate colder temperatures and fast longer (Newton 1979, Kerlinger 1989, Clarke 1995, Simmons 2000). For this reason, males, too small also to compete with females for carrion (Clarke 1995), could have a stronger tendency to migrate over a long distance after leaving their breeding areas, crossing the Central Mediterranean in large numbers (Agostini and Logozzo 2000). Why, then, did females outnumber males in our study? In late spring and summer 2003 the weather was abnormally warm in Europe and the heat was exacerbated by drought (Wagner 2003). Since rainfall influences habitat productivity and food abundance (Redpath et al. 2002), data recorded in 2003 could suggest the hypothesis that higher numbers of adult females left Europe after the anomalous weather during the breeding season, outnumbering males crossing the central Mediterranean. This imbalance, would reflect the fact that females outnumber males in several European populations of this species (Simmons 2000).

Our observations confirm that the greatest concentration of Egyptian Vultures Neophron percnopterus during autumn migration through Italy occurs at the island of Marettimo (Agostini et al. 2000). In particular, at this site 70 individuals (nearly all adults) were seen in 1998. During our observations the passage of 62 adults, 4 sub-adults and 6 juveniles was reported at this site; all juveniles were seen flying in flocks of adults. Two adults were recorded over Pantelleria. In Italy it has been estimated a breeding population of 15-20 pairs, mostly in western Sicily (Brichetti and Fracasso 2003). Considering that a recent study made in western Sicily reported a breeding success of 0.89 juveniles per pair (Di Vittorio et al. 2003), during autumn migration about 30-40 adults and 13-18 juveniles are expected to cross the central Mediterranean. The large number of adults reported over Marettimo seems to confirm that tens of non breeding Egyptian Vultures, presumably summering in Italy, use this route (Agostini et al. 2000). Moreover, the observation of mixed-age flocks suggests that at least part of juveniles belonging to the Italian population possibly are able to learn this route by following adults during their first migration.

This study confirms that lower numbers of Montagu's Harriers (Circus pygargus) cross the Central Mediterranean during autumn than during spring migration 
(Agostini and Logozzo 1997, Agostini et al. 2000, Corso 2001, Guglielmi et al. 2003), while the opposite situation occurs at the Straits of Gibraltar (Finlayson 1992, García and Arroyo 1998). Montagu's Harriers, differently from the other longdistance migrants (Kjellén 1992), apparently do not suspend moult during autumn migration (Arroyo and King 1996). These raptors fly slowly and go hunting along the way (Ali and Ripley 1978) perhaps to continue moulting while migrating (Arroyo and King 1996). Since gaps in the wing would involve higher energetic costs during the powered flight over water, Agostini and Logozzo (1997) suggested that many Montagu's Harriers undertaking the long crossing of the Central Mediterranean during spring migration, choose a different route during autumn, perhaps concentrating at the Straits of Gibraltar.

Finally, considering the huge number of Accipitriformes observed over Pantelleria (over 3000; Grimmet and Jones 1989), this island, so as Marettimo (Agostini $e t$ al. 2000), should be enclosed among Important Bird Areas for the autumn migration of raptors in the Mediterranean basin.

\section{ACKNOWLEDGEMENTS}

This research has been partially made within the activities of the Stazione di Inanellamento of Palermo, funded by the Assessorato Agricoltura e Foreste of the Regione Siciliana. We wish to thank Angelo Nitti, Vittorio Giacoia and Franco De Salvo for their help during observations at Marettimo. Anthony Green provided valuable comments on the manuscript to improve the English.

\section{REFERENCES}

Agostini N. 2001. Spring migration in relation to sex and age of Marsh Harriers Circus aeruginosus in a central Mediterranean island. Ardeola 48: 71-73.

Agostini N., Coleiro C., Corbi F., Di Lieto G., Pinos F., Panuccio M. 2001. Comparative study on the autumn migration of Marsh Harriers (Circus aeruginosus) at three sites of the Central Mediterranean. Vogelwarte 41: 154-158.

Agostini N., Coleiro C., Corbi F., Di Lieto G., Pinos F., Panuccio M. 2002. Water-crossing tendency of juvenile Honey Buzzards during migration. Avocetta 26: 41-43.

Agostini N., Coleiro C., Panuccio M. 2003. Autumn migration of Marsh Harriers (Circus aeruginosus) across the central Mediterranean in 2002. Ring 25: 47-52.

Agostini N., Coleiro C., Panuccio M. 2004. Analysis of the autumn migration of juvenile Honey Buzzards (Pernis apivorus) across the central Mediterranean. J. Raptor Res. 38: 283-286.

Agostini N., Logozzo D. 1995. Autumn migration of Honey Buzzards in southern Italy. J. Raptor Res. 29: 275-277.

Agostini N., Logozzo D. 1997. Autumn migration of Accipitriformes through Italy en route to Africa. Avocetta 21: 174-179.

Agostini N., Logozzo D. 2000. Migration and wintering distribution of the Marsh Harrier Circus aeruginosus in southern Italy. Buteo 11: 19-24.

Agostini N., Logozzo D., Coleiro C. 1999. The orientation/navigation hypothesis: an indirect evidence in migrating Honey Buzzards. Riv. Ital. Orn. 69: 153-159. 
Agostini N., Logozzo D., Panuccio M. 2000. The island of Marettimo (Italy),important bird area for the autumn migration of raptors. Avocetta 24: 95-99.

Ali S., Ripley S.D. 1978. Handbook of the birds of India and Pakistan. vol. I. Oxford Univ. Press., Oxford.

Arroyo B.E., King J.R. 1996. Age and sex differences in molt of the Montagu's Harrier. J. Raptor Res. 30: 224-233.

Brichetti P., Fracasso G. 2003. Ornitologia Italiana. Perdisa Editore, Bologna, Italy.

Chiavetta M. 1981. I rapaci d'Italia e d'Europa. Rizzoli, Milano.

Clarke R. 1995. The Marsh Harrier. Hamlyn, London.

Corso A. 2001. Raptor migration across the Strait of Messina, southern Italy. Brit. Birds 94: 196-202.

Cramp S., Simmons K.E.L. 1980. The Birds of the Western Palearctic. Handbook of the Birds of Europe, the Middle East and North Africa. vol. 2. Oxford Univ. Press, Oxford, UK.

Di Vittorio M., Diliberto N., Campobello D. 2003. Status e biologia del Capovaccaio Neophron percnopterus in Sicilia. Avocetta 27: 41.

Finlayson C. 1992. Birds of the Strait of Gibraltar. London, T \& A D Poyser.

Forsman D. 1999. The raptors of Europe and the Middle East: a Handbook of Field Identification. T \& A D Poyser, London.

Galea C., Massa B. 1985. Notes on the raptor migration across the central Mediterranean. ICPB Tech. Publ. 5: 257-261.

Garcìa J.T., Arroyo B. 1998. Migratory movements of western European Montagu's Harrier Circus pygargus: a review. Bird Study 45: 188-194.

Grimmet R.A., Jones T.A. 1989. Important Bird Areas in Europe. International Council for Bird Preservation, IUCP Tech. Publ. 9. Cambridge, UK.

Guglielmi R., Repaci E., Morabito N. 2003. La migrazione post-nuziale di Accipitriformi e Falconiformi in Aspromonte. Avocetta 27: 69.

Kerlinger P. 1989. Flight strategies of migrating hawks. Univ. Chicago Press, Chicago, USA.

Kjellén N. 1992. Differential timing of autumn migration between sex and age groups in raptors at Falsterbo, Sweden. Ornis Scand. 23: 420-434.

Newton I. 1979. Population Ecology of raptors. T \& A D Poyser, London.

Panuccio M., Agostini N., Massa B. 2002. Crossing the Tyrrhenian Sea, spring migration of Marsh Harriers (Circus aeruginosus), sex classes and relation to wind conditions. Vogelwarte 41: 271-275.

Rebassa M. 1995. La migraciò postnupcial de rapinyaires a l'illa de Cabreara: trets generals. Anuari ornitològic de les Balears 1995.

Redpath S.M., Arroyo B., Etheridge B, Leckie F., Bouwman K., Thirgood S.J. 2002. Temperature and hen harrier productivity: from local mechanisms to geographical patterns. Ecography 25: 533-540.

Schneider-Jacoby M. 2001. Lastovo - a new bottleneck site for the migratory Honey Buzzards (Pernis apivorus). Acrocephalus 22: 163-165.

Simmons R.E. 2000. Harriers of the world. Their behaviour and Ecology. Oxford Ornithol. Ser., Oxford, UK.

Wagner A.J. 2003. Mean circulation highlights and climate anomalies March through August 2003. Mariners Weather Log 47, 2: online (http://vos.noaa.gov/MWL/fall_03/circulation.shtml). 